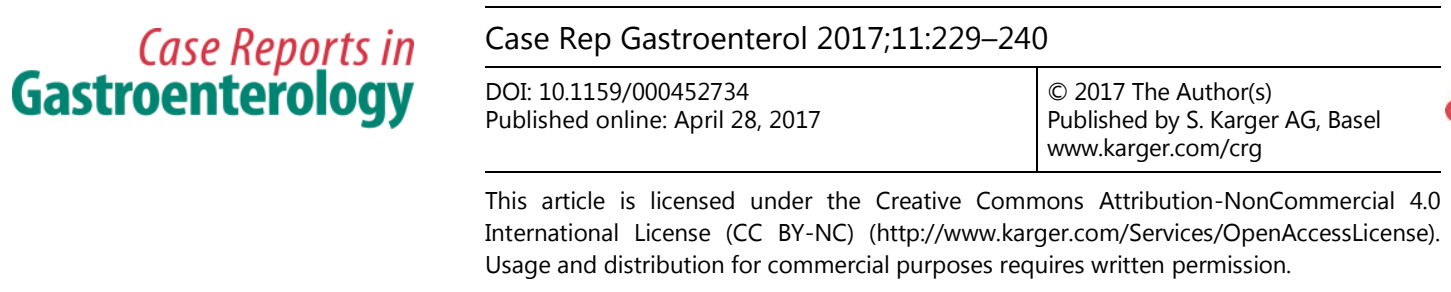

\title{
Long-Term Results of Serial Transverse Enteroplasty with Neovalve Creation for Extreme Short Bowel Syndrome: Report of Two Cases
}

\author{
Mireia Botey ${ }^{a}$ Antonio Alastrué ${ }^{b}$ Henrik Haetta $^{b}$ \\ Jaume Fernández-Llamazares ${ }^{b} \quad$ Arantxa Clavell $^{b}$ Pau Moreno ${ }^{b}$ \\ ${ }^{a}$ Hospital General de Catalunya, Sant Cugat del Vallès (Barcelona), Spain; \\ ${ }^{\mathrm{b}}$ Hospital Germans Trias i Pujol, Badalona (Barcelona), Spain
}

\section{Keywords}

Short bowel syndrome $\cdot$ Citrulline $\cdot$ Serial transverse enteroplasty $\cdot$ Ileocecal valve $\cdot$ Neovalve

\begin{abstract}
Objective: The aim of this article was to determine whether serial transverse enteroplasty (STEP) and the creation of a new ileocecal valve in extreme short bowel syndrome (SBS) cases $(<45 \mathrm{~cm})$ is effective in intestinal adaptation and improvement of nutritional parameters and serum citrulline levels. Patients and Methods: We present 2 cases of SBS treated with STEP. Enterectomy was performed for massive intestinal ischemia secondary to a gastrointestinal stromal tumor in the first case and to catastrophic antiphospholipid syndrome in the second. After enterectomy, the short residual bowel measured $34 \mathrm{~cm}$ in the first patient and $45 \mathrm{~cm}$ in the second. In both cases STEP, cholecystectomy, and gastrostomy were performed. In the first case a Brooke neovalve was created, and in the other the ileocecal valve was preserved. Results: Both patients could finally be weaned off total parenteral nutrition (TPN) and gastrostomy feeding, maintaining a good nutritional status 1 year after surgery. Conclusions: In extreme SBS, a minimum length of $80-90 \mathrm{~cm}$ of functioning small bowel and an intact ileocecal valve are necessary. We plead for the use of STEP with preservation of the ileocecal valve
\end{abstract}


or creation of a neovalve using the Brooke technique in order to achieve the ultimate goal, which is to wean patients off TPN. After a critical review of different surgical techniques, a treatment algorithm is proposed.

\section{Introduction}

Short bowel syndrome (SBS) implies anatomical and functional loss of intestine with subsequent absorptive surface deficiency and metabolic alterations [1]. In pediatric groups, mortality rates of $37.5 \%$ at 5 years were described $[2,3]$, due to septic complications (bacterial overgrowth, catheter-related sepsis) [4-6] and total parenteral nutrition (TPN)-related liver failure [7-9]. Intestinal adaptation is a key process through which a patient affected by SBS recovers digestive capacity, depending on the length of the residual bowel, the presence of a ileocecal valve/neovalve, and colon preservation. Other factors that contribute to intestinal adaptation are the individual ability to develop hyperphagia, the increase in and hypertrophy of intestinal villi, the delay of digestive transit and, last but not least, a dedicated multidisciplinary team. The clinical course and serum biomarkers such as citrulline (nonessential amino acid produced exclusively by enterocytes) [10] will guide the therapeutic approach. In case of deficient intestinal adaptation, different surgical options are available. These techniques aim at increasing the absorptive surface through bowel lengthening and restoration of ileocecal valve function in order to prevent bacterial overgrowth. In all cases, the goal is to obtain an adequate nutritional status that can be maintained without TPN [11].

\section{Case Presentation}

Case 1

A 52-year-old male underwent massive bowel resection with end jejunostomy and cecostomy without ileocecal valve preservation for mesenteric thrombosis secondary to a gastrointestinal stromal tumor. Gastrointestinal transit showed a residual bowel length of $34 \mathrm{~cm}$ (Fig. 1). After 4 weeks of exclusive TPN, citrulline levels were $<20 \mu \mathrm{mol} / \mathrm{L}$, and the patient had presented several episodes of dehydration and hyponatremia due to jejunostomy losses. It was decided to restore the intestinal transit with serial transverse enteroplasty (STEP), aimed at obtaining a small bowel length of $80 \mathrm{~cm}$. This required 10 endostaplers of $4.5 \mathrm{~cm}$ (calculated length $=34 \mathrm{~cm}+[10 \times 4.5 \mathrm{~cm}]$ ), placed alternatively onto the antimesenteric and mesenteric border at $3-\mathrm{cm}$ intervals, taking special care to avoid injuring the vascularization (Fig. 2, Fig. 3). A Brooke-type neovalve was created, anastomosing the distal jejunum to the cecum $[12,13]$. Cholecystectomy and feeding gastrostomy were also performed. For 5 weeks postoperatively, the patient required TPN and enteral nutrition, oral supplements of pancreatic enzymes, proton pump inhibitors, vitamin B12, and codeine and loperamide as needed. Serum citrulline levels 2 months after surgery surpassed $20 \mu \mathrm{mol} / \mathrm{L}$. After 2 months, TPN could be stopped and the patient was discharged on an oral specific diet $(500 \mathrm{~mL})$ complemented by nocturnal enteral nutrition $(1,000 \mathrm{~mL})$, with $2-3$ soft stools per day. After 6 months, the gastrostomy was removed. One year after surgery the patient had gained $14 \mathrm{~kg}$ ( $48 \mathrm{vs} .34 \mathrm{~kg}$ before surgery) and had a stable nutritional status, with oral supplementation and routine follow-up by a nutritionist. 


\section{Case Reports in \\ Gastroenterology}

Case Rep Gastroenterol 2017;11:229-240

DOI: 10.1159/000452734

(c) 2017 The Author(s). Published by S. Karger AG, Basel www.karger.com/crg

Botey et al.: Long-Term Results of Serial Transverse Enteroplasty with Neovalve Creation for Extreme Short Bowel Syndrome: Report of Two Cases

Case 2

A 30-year-old woman developed mesenteric ischemia due to catastrophic antiphospholipid syndrome, requiring a massive intestinal resection with end jejunostomy $45 \mathrm{~cm}$ from the Treitz angle and end ileostomy $7 \mathrm{~cm}$ from the ileocecal valve. The patient had the 4 criteria of catastrophic antiphospholipid syndrome: involvement of 3 or more organs, simultaneous development of manifestations, antiphospholipid antibodies, and histological confirmation of small vessel thrombosis $[14,15]$. In this case, catastrophic antiphospholipid syndrome appeared to be induced by an active tuberculosis that was diagnosed and treated later. Over the next 2 months, the patient required TPN, anticoagulation, and specific treatment for pulmonary tuberculosis reactivation. Constant vomiting was attributed to hyperphagia, a common occurrence related to SBS [9]. Afterwards, she underwent surgery to restore intestinal continuity. Due to necrosis of the terminal ileum with only $4 \mathrm{~cm}$ of terminal ileum left, jejunoileal anastomosis at the ileocecal valve was practiced and STEP was performed as in the previous case, using 12 stapler cartridges to obtain a total length of small bowel of $90 \mathrm{~cm}$ (calculated length $=45 \mathrm{~cm}+[12 \times 4.5 \mathrm{~cm}]$ ). Cholecystectomy and gastrostomy were also performed. Postoperatively, the gastrostomy had a persistent output of $1,500 \mathrm{~mL} /$ day. Upper gastrointestinal series performed through gastrostomy showed a stop in the third portion of the duodenum. Magnetic resonance angiography confirmed the diagnosis of superior mesenteric artery syndrome with perivascular fibrosis and intravascular thrombus (Fig. 4). Corticosteroid treatment was initiated and a feeding jejunostomy tube was placed endoscopically, with the catheter tip distal to the stenotic area. Subsequent improvement was observed over the next 2 weeks, with a decrease in gastrostomy output and better tolerance of oral liquid nutrition. Citrulline levels before surgery were $<20 \mu \mathrm{mol} / \mathrm{L}$ and 2 months after STEP hade risen above this level. TPN was stopped and the patient was discharged with oral supplements. At 1 year after surgery, tuberculosis treatment was completed and intestinal function was correct, with a weight gain of $16 \mathrm{~kg}$ (64 vs. $48 \mathrm{~kg}$ before surgery). A minimal dose of corticosteroids and low-molecular-weight heparin was necessary as maintenance treatment.

\section{Review}

SBS is defined as a reduction in the total capacity of the intestine, with or without resection, below the minimum level required for proper digestion and absorption of nutrients as well as to provide an adequate fluid and electrolyte balance [8, 12]. Functional bowel capacity does not depend on its real length, but on its capacity and mucosal integrity. Citrulline is a nonessential amino acid synthesized in the enterocyte from glutamine and other amino acids and is not used for protein synthesis $[10,16]$. It is a specific biomarker of intestinal function in patients with normal renal function $[11,17]$ and a good marker of enterocyte load. Optimal serum levels should be at least $20 \mu \mathrm{mol} / \mathrm{L}$ [18]. If these levels are not reached in due time, surgical techniques of bowel lengthening should be used.

Planning of surgery in cases of SBS should take into account the presence or absence of the ileocecal valve [12-14]. It acts as a barrier against reflux of colonic contents and flora and regulates the flow of fluids and nutrients from the bowel to the colon. If it is preserved, the time of contact between nutrients and intestinal mucosa increases, allowing more absorption to take place. Otherwise, rapid transit and small intestinal bacterial overgrowth (SIBO) weaken the patient's condition. 
Colon preservation is crucial for adaptation. The colon retains fluids and electrolytes, absorbs proteins, and rescues unabsorbed carbohydrates due to bacterial metabolism, transforming them into short-chain fatty acids which are directly absorbed into the portal circulation [15, 17-19]. Additionally, the colon decreases digestive motility and stimulates adaptation through peptide YY release. Nevertheless, there are some drawbacks related to colon preservation in patients with SBS. One of them is the increase in the amount of free oxalate that reaches the colon and which is absorbed and excreted by the kidneys, increasing the incidence of calcium oxalate stones. Another drawback is the generation of D-lactates (through fermentation of unabsorbed carbohydrates) which are absorbed and cause neurological symptoms such as chronic fatigue, confusion, convulsions, and in some cases coma.

One classification distinguishes 3 types of SBS (Fig. 5), depending on the presence or absence of a jejunostomy and the preservation or not of the ileocecal valve and the colon [8]. Other authors subdivide SBS patients into absorbers (if they have $>80 \mathrm{~cm}$ of jejunum) and secretors (if the length is $<80 \mathrm{~cm}$ ) [19]. Each SBS type has disadvantages: (1) Jejunostomy causes important fluid loss resulting in a lack of water, sodium, and magnesium as well as a volume reduction of digestive secretions (gastric and pancreatic juice and bile). Its consequences are malabsorption, malnutrition, and gallstone formation [8]. (2) Jejunocolic anastomosis causes malabsorption with diarrhea, steatorrhea, malnutrition, vitamin B12 deficiency, and renal and biliary stones.

Intestinal adaptation is a process which attempts to restore the intestinal absorption of nutrients, minerals, vitamins, and water $[11,16]$. This process involves 3 factors $[19,20]$ : hyperphagia, structural adaptation, and functional adaptation. Structural adaptation consists of an increase in diameter and height of the intestinal villi, thickening of the intestinal wall, and increase in endoluminal diameter, with a subsequent increase in absorption surface. Functional adaptation consists of an increase in the rate of nutrient absorption due to structural changes, slower intestinal transit, and molecular events such as a change in enterocyte intrinsic enzymatic activity transport. Adaptation will depend on the bowel length, the presence or absence of the ileocecal valve and colon, the patient's age, and the multidisciplinary teamwork [21]. The adaptive changes enumerated before will progressively increase the bowel's efficiency. During adaptation, specific light nutrients such as glutamine, short-chain fatty acids, unsaturated fat, ornithine, and nucleotides are necessary in order to stimulate the enterocytes to release trophic factors [22]. Gastrointestinal hormones such as GLP-1 also stimulate adaptation, especially in enterocyte cells of the terminal ileum and colon. SIBO occurs when the regulatory mechanisms of the intestinal flora are altered and there is no barrier against colonization with colonic flora $[23,24]$. Streptococci, Bacteroides, Escherichia spp., lactobacilli, and others, in addition to structural adaptation, cause SIBO. The consequences negatively affect digestion, nutrient uptake, and bile acid conjugation. Subsequently, fat malabsorption occurs, with steatorrhea and deficit in vitamins A, D, and E, while vitamin $\mathrm{K}$ is not altered as it is synthesized by the bacteria themselves. Bloating is a consequence of carbohydrate malabsorption [25]. In the worst case, SIBO causes inflammatory changes in the mucosa, with increased permeability and an increased risk of bacterial translocation and sepsis. An indirect diagnosis of SIBO is obtained using the hydrogen breath test or by determination of serum levels of D-lactic acid. A direct diagnosis is made by determination of bacterial concentrations in duodenal/jejunal aspirate.

Other secondary factors are anastomotic ulcers, chronic bleeding (iron deficiency anemia), hepatic steatosis [26], and TPN-induced toxicity. Bacterial endotoxin activates inflammatory cytokines (TNF), which in turn interfere with the fusion of membrane transporter hepatocytes $[27,28]$. 
Surgery in the SBS is indicated in patients who fail to thrive without TPN and who have citrulline levels $<20 \mu \mathrm{mol} / \mathrm{L}$ despite proper nutrition and sufficient time to adapt. If a patient's absorptive capacity does not improve within 6 months and adaptation does not occur, SBS is diagnosed [29]. However, in patients with an intestinal length $<40 \mathrm{~cm}$ and without ileocecal valve, SBS can be diagnosed from the beginning.

Before using any lengthening technique, other procedures must be performed in order to improve motility, reduce the dilated areas, and prevent SIBO [24, 30, 31]. Surgeons' mission is to: (1) Remove the dysfunctional intestine (pathological dilatations, incomplete obstructions, postischemic stenosis). Plications or taperings, bipartitions in continuity or double-barreled gun (DBG) (Fig. 5), or STEP can be performed. We consider that we should act on the intestinal dilated segments to improve length and not motility, advocating thus for DBG or STEP. (2) Improve length slowing motility through neovalve creation. This entails the use of any surgical technique that reshapes the short bowel, unable to adapt, either by lengthening it or creating new valves to prevent SIBO and improving absorption time (Fig. 5) [32]. SBS surgery represents every actuation in the bowel in order to expand the area of absorption. First, restore the bowel continuity if the patient has an ostomy. Only the fact of anastomosing the jejunum to the remaining intestine increases length and transit time [33]. Figure 5 illustrate the types of procedures employed to lengthen the bowel. Some procedures are isoperistaltic, such as the Bianchi technique (longitudinal elongation) [34] or the Kimura-Soper technique (transverse elongation) [35] with its innovative concept of anastomosing the seromuscular bowel layer to the liver or to the abdominal wall. Our opinion is that although these classical techniques are conceptually attractive, they are difficult and risky, and we advocate for the use of STEP [35].

Gallstones appear in a high percentage of patients with SBS. Their etiology is related to bile stasis and malabsorption. It is therefore recommended to practice cholecystectomy in patients who require extensive intestinal resections [34]. The aim of surgery in SBS is to preserve or create as much intestinal length as possible and restore the intestinal continuity following a treatment algorithm in each case (Fig. 6). Citrulline levels will guide the therapeutic approach, indicating the necessity of surgery and its efficacy. The key is to restore intestinal continuity for its advantages: it allows the distal intestinal mucosa to regain functionality, slows down intestinal transit time, and increases the absorption of liquids. Nevertheless, in the first phase after reconstruction diarrhea occurs, leading to perineal irritation and possible formation of oxalate nephrolithiasis.

In other cases, when surgery can favor a reasonable adaptation, the options are: (1) If the residual intestine length is $<40 \mathrm{~cm}$ and the ileocecal valve is preserved, it may be feasible to indicate STEP [36-38]. (2) If the residual intestine length is $>80 \mathrm{~cm}$ without ileocecal valve, it is necessary to create a new valve and evaluate the necessity of STEP. (3) If the residual intestine length is between 40 and $80 \mathrm{~cm}$, there are several options that we describe in the algorithm presented in Figure 6, including a new technique, the DBG, similar to the Bianchi technique, but without anastomotic risk, stenosis, or loss of bowel secondary to ischemia. In our opinion, the technique described by Kimura and Soper and the tapering technique for segmental dilations are too risky. Other techniques, such as reversed intestinal segments [39, 40], electrical pacing [41-43], antiperistaltic segments [44, 45], use of small bowel neomucosa [11,46], artificial sphincter [47-49], intestinal recirculation, intrinsic myenteric denervation, or colon interposition, have been anecdotally performed, and it is difficult to generalize their results. Interventions such as elongation after intestinal bipartition (longitudinal intestinal lengthening and tailoring) [50-52] or DBG are useful and applicable in cases of long dilated segments. However, we consider STEP [36] the ideal procedure 
Botey et al.: Long-Term Results of Serial Transverse Enteroplasty with Neovalve Creation for Extreme Short Bowel Syndrome: Report of Two Cases

because it avoids the loss of mucosal surface capable of adequate absorption and is devoid of anastomotic risk. Its technique allows to calculate the number of stapler cartridges required to achieve the required length in each case. STEP has intrinsic advantages: it is easy to perform, avoids anastomosis, may increase the bowel length to more than double or triple, and may also be used in a secondary procedure. Our opinion is that any surgical approach must be prudent, without risk of loss or deterioration of the physical surface of the intestine, but always with the aim of weaning the patient off TPN, which is absolutely necessary during adaptation, but dangerous in the long run.

In this article, we reviewed the surgical principles that should be applied when approaching a patient with SBS and the procedures currently available. The large number of published anecdotal techniques indicates that none of them is ideal. The low number of patients in each group and the lack of long-term effectiveness results do not allow to draw definitive conclusions. SBS is a devastating condition, and the main therapeutic goal is to increase the intestinal absorptive surface up to the point that will allow weaning off TPN. In the first stages of SBS, TPN is crucial for survival and afterwards continues to be very important during the adaptation process, until surgery can be performed. Based on these principles and on our experience with the cases described above, we propose a treatment algorithm for SBS (Fig. 6). In our view, STEP is a very useful, easy to perform, and reproducible alternative that allows significant intestinal lengthening without anastomotic risk. The proportion of patients with SBS who achieve full functional autonomy is increasing. Intestinal transplantation will be reserved for cases with a bowel length $<40 \mathrm{~cm}$ and TPN-related colon or liver sequelae [53-55]. Currently, intestinal transplantation has a questionable and difficult to predict long-term outcome when compared with successful intestinal adaptation.

\section{Statement of Ethics}

There are no ethical conflicts.

\section{Disclosure Statement}

There are no conflicts of interest.

\section{References}

1 Ballesteros Pomar MD, Vidal Casariego A: Short bowel syndrome: definition, causes, intestinal adaptation and bacterial overgrowth (in Spanish). Nutr Hosp 2007;22(suppl 2):74-85.

$\checkmark 2$ Diamanti A, Basso MS, Castro M, Calce A, Pietrobattista A, Gambarara M: Prevalence of life-threatening complications in pediatric patients affected by intestinal failure. Transplant Proc 2007;39:1632-1633.

- Goulet OJ, Revillon Y, Jan D, De Potter S, Maurage C, Lortat-Jacob S, Martelli H, Nihoul-Fekete C, Ricour C: Neonatal short bowel syndrome. J Pediatr 1991;119:18-23.

4 Sondheimer JM, Asturias E, Cadnapaphornchai M: Infection and cholestasis in neonates with intestinal resection and long-term parenteral nutrition. J Pediatr Gastroenterol Nutr 1998;27:131-137.

5 Gracey M: The contaminated small bowel syndrome: pathogenesis, diagnosis and treatment. Am J Clin Nutr 1979;32:234-243.

-6 Kaufman SS, Loseke CA, Lupo JV, Young RJ, Murray ND, Pinch LW, Vanderhoof JA: Influence of bacterial overgrowth and intestinal inflammation on duration of parenteral nutrition in children with short bowel syndrome. J Pediatr 1997;131:356-361.

7 Dorney SF, Ament ME, Berquist WE, Vargas JH, Hassall E: Improved survival in very short small bowel of infancy with use of long-term parenteral nutrition. J Pediatr 1985;107:521-525. 
Botey et al.: Long-Term Results of Serial Transverse Enteroplasty with Neovalve Creation for Extreme Short Bowel Syndrome: Report of Two Cases

-8 Wilson WA, Gharavi AE, Koike T, Lockshin MD, Branch DW, Piette JC, Brey R, Derksen R, Harris EN, Hughes GR, Triplett DA, Khamashta MA: International consensus statement on preliminary classification criteria for definite antiphospholipid syndrome: report of an international workshop. Arthritis Rheum 1999;42:1309-1311.

-9 Nightingale J, Woodward JM; Small Bowel and Nutrition Committee of the British Society of Gastroenterology: Guidelines for management of patients with a short bowel. Gut 2006;55(suppl 4) iv1-iv12.

10 Ricour C, Gorski AM, Goulet O, De Potter S, Corriol O, Postaire M, Nihoul-Fekete C, Jan D, Revillon Y, Lortat-Jacob S, Pellerin D: Home parenteral nutrition in children: 8 years of experience with 112 patients. Clin Nutr 1990;9:65-71.

11 Nordgaard I, Hansen BS, Mortensen PB: Colon as a digestive organ in patients with short bowel. Lancet 1994;343:373-376.

$\$ 12$ Kim HB, Fauza D, Garza J, Oh JT, Nurko S, Jaksic T: Serial transverse enteroplasty (STEP): a novel bowel lengthening procedure. J Pediatr Surg 2003;38:425-429.

13 Bueno J: Surgical strategies in short bowel syndrome (in Spanish). Nutr Hosp 2007;22(suppl 2):103112.

14 Carbonnel F, Cosnes J, Chevret S, Beaugerie L, Ngô Y, Malafosse M, Parc R, Le Quintrec Y, Gendre JP: The role of anatomic factors in nutritional autonomy after extensive small bowel resection. JPEN J Parenter Enteral Nutr 1996;20:275-280. Jenkins AP, Thompson RP: Mechanisms of small intestinal adaptation. Dig Dis 1994;12:15-27.

16 Crenn P, Morin MC, Joly F, Penven S, Thuillier F, Messing B: Net digestive absorption and adaptive hyperphagia in adult short bowel patients. Gut 2004;53:1279-1286.

17 Curis E, Crenn P, Cynober L: Citrulline and the gut. Curr Opin Clin Nutr Metab Care 2007;10:620-626.

$>18$ Jeejeebhoy KN: Management of short bowel syndrome: avoidance of total parenteral nutrition. Gastroenterology 2006;130(2 suppl 1):S60-S66.

19 Crenn P, Coudray-Lucas C, Thuillier F, Cynober L, Messing B: Postabsorptive plasma citrulline concentration is a marker of absorptive enterocyte mass and intestinal failure in humans. Gastroenterology 2000;119:1496-1505.

20 Gazet JC: The surgical significance of the ileo-caecal junction. Ann R Coll Surg Engl 1968;43:19-38.

21 Gambarara M, Ferretti F, Papadatou B, Lucidi V, Diamanti A, Bagolan P, Bella S, Castro M: Intestinal adaptation in short bowel syndrome. Transplant Proc 1997;29:1862-1863.

$\checkmark 22$ Lo CW, Walker WA: Changes in the gastrointestinal tract during enteral or parenteral feeding. Nutr Rev 1989;47:193-198.

-23 Vanderhoof JA, Langnas AN: Short-bowel syndrome in children and adults. Gastroenterology 1997;113: 1767-1778.

-24 Ricotta J, Zuidema GD, Gadacz TR, Sadri D: Construction of an ileocecal valve and its role in massive resection of the small intestine. Surg Gynecol Obstet 1981;152:310-314.

-25 Ziegler TR, Fernández-Estívariz C, Gu LH, Bazargan N, Umeakunne K, Wallace TM, Diaz EE, Rosado KE, Pascal RR, Galloway JR, Wilcox JN, Leader LM: Distribution of the H+/peptide transporter PepT1 in human intestine: up-regulated expression in the colonic mucosa of patients with short-bowel syndrome. Am J Clin Nutr 2002;75:922-930.

-26 Quigley EMM, Quera R: Small intestinal bacterial overgrowth: roles of antibiotics, prebiotics, and probiotics. Gastroenterology 2006;130(2 suppl 1):S78-S90.

27 Teitelbaum DH, Tracy T: Parenteral nutrition-associated cholestasis. Semin Pediatr Surg 2001;10:7280.

28 Colomb V, Goulet O, De Potter S, Ricour C: Liver disease associated with long-term parenteral nutrition in children. Transplant Proc 1994;26:1467.

29 Warner BW, Chaet MS: Nontransplant surgical options for management of the short bowel syndrome. J Pediatr Gastroenterol Nutr 1993;17:1-12.

-30 Botha JF, Grant WJ, Torres C, Iverson AK, Sudan DL, Shaw BW Jr, Langnas AN: Isolated liver transplantation in infants with end-stage liver disease due to short bowel syndrome. Liver Transpl 2006;12:1062-1066.

-31 Devine RM, Kelly KA: Surgical therapy of the short bowel syndrome. Gastroenterol Clin North Am 1989;18:603-618.

-32 Goulet O, Ruemmele F, Lacaille F, Colomb V: Irreversible intestinal failure. J Pediatr Gastroenterol Nutr 2004;38:250-269.

-33 Mackby JM, Richard V, Gilfillans RS, Florida R: Methods of increasing the efficiency of residual small bowel segments. A preliminary study. Am J Surg 1965;109:32-38.

-34 Bianchi A: Intestinal loop lengthening. A technique for increasing small intestinal length. J Pediatr Surg 1980;15:145-151.

-35 Kimura K, Soper RT: A new bowel elongation technique for the short-bowel syndrome using the isolated bowel segment Iowa models. J Pediatr Surg 1993;28:792-794. 


\section{Case Reports in \\ Gastroenterology}

\begin{tabular}{l|l}
\hline Case Rep Gastroenterol 2017;11:229-240 \\
\hline DOI: 10.1159/000452734 & $\begin{array}{l}\text { C 2017 The Author(s). Published by S. Karger AG, Basel } \\
\text { www.karger.com/crg }\end{array}$ \\
\hline
\end{tabular}

Botey et al.: Long-Term Results of Serial Transverse Enteroplasty with Neovalve Creation for Extreme Short Bowel Syndrome: Report of Two Cases

-36 Georgeson K, Halpin D, Figueroa R, Vincente Y, Hardin W Jr: Sequential intestinal lengthening procedures for refractory short bowel syndrome. J Pediatr Surg 1994;29:316-320; discussion 320-321. Fryer JP: Intestinal transplantation: current status. Gastroenterol Clin North Am 2007;36:145-159. Javid PJ, Kim HB, Duggan CP, Jaksic T: Serial transverse enteroplasty is associated with successful shortterm outcomes in infants with short bowel syndrome. J Pediatr Surg 2005;40:1019-1023.

39 Wales PW, Dutta S: Serial transverse enteroplasty as primary therapy for neonates with proximal jejunal atresia. J Pediatr Surg 2005;40:E31-E34.

40 Duggan C, Piper H, Javid PJ, Valim C, Collier S, Kim HB, Jaksic T: Growth and nutritional status in infants with short-bowel syndrome after the serial transverse enteroplasty procedure. Clin Gastroenterol Hepatol 2006;4:1237-1241.

-41 Layzell T, Collin J: Retrograde electrical pacing of small intestine: a new treatment for the short bowel syndrome? Br J Surg 1981;68:711-713.

42 Pertsemlidis D, Kark AE: Antiperistaltic segments for the treatment of short bowel syndrome. Am J Gastroenterol 1974;62:526-530.

-43 Watson LC, Friedman HI, Griffin DG, Norton LW, Mellick PW: Small bowel neomucosa. J Surg Res 1980;28:280-291.

Pothe E: Use of gastrointestinal reversal in surgical procedures. Am J Surg 1969;118:893-899. Sawchuk A, Nogami W, Goto S, Yount J, Grosfeld JA, Lohmuller J, Grosfeld MD, Grosfeld JL: Reverse electrical pacing improves intestinal absorption and transit time. Surgery 1986;100:454-460.

-46 Nightingale JM, Lennard-Jones JE, Walker ER, Farthing MJ: Jejunal efflux in short bowel syndrome. Lancet 1990;336:765-768.

47 Pigot F, Messing B, Chaussade S, Pfeiffer A, Pouliquen X, Jian R: Severe short bowel syndrome with a surgically reversed small bowel segment. Dig Dis Sci 1990;35:137-144.

-48 Panis Y, Messing B, Rivet P, Coffin B, Hautefeuille P, Matuchansky C, Rambaud JC, Valleur P: Segmental reversal of the small bowel as an alternative to intestinal transplantation in patients with short bowel syndrome. Ann Surg 1997;225:401-407.

49 Binnington HB, Tumbleson ME, Ternberg JL: Use of jejunal neomucosa in the treatment of short gut syndrome in pigs. J Pediatr Surg 1975;10:617-621.

50 Stacchini A, DiDio LJ, Primo ML, Borelli V, Andretto R: Artificial sphincters as surgical treatment for experimental massive resection of small intestine. Am J Surg 1982;143:721-726.

51 López GA, Gaztambide J, Quadri A: Intestinal recirculation in the management of experimental short bowel syndrome (in Spanish). An Esp Pediatr 1975;8:243-248.

52 García SB, Kawasaky MC, Silva JC, García-Rodrígues AC, Borelli-Bovo TJ, Iglesias AC, Zucoloto S: Intrinsic myenteric denervation: a new model to increase the intestinal absorptive surface in short-bowel syndrome. J Surg Res 1999;85:200-203.

\$53 Lloyd DA: Colonic interposition between the jejunum and ileum after massive small bowel resection in rats. Prog Pediatr Surg 1978;12:51-106.

54 Brolin RE: Colon interposition for extreme short bowel syndrome: a case report. Surgery 1986;100: 576-580.

-55 Modi BP, Javid PJ, Jaksic T, Piper H, Langer M, Duggan C, Kamin D, Kim HB; on behalf of the International STEP Data Registry: First report of the international serial transverse enteroplasty data registry: indications, efficacy, and complications. J Am Coll Surg 2007;204:365-371. 


\begin{tabular}{ll|l} 
Case Reports in & \begin{tabular}{l} 
Case Rep Gastroenterol 2017;11:229-240 \\
\cline { 2 - 3 } Gastroenterology
\end{tabular} & $\begin{array}{l}\text { DO 2017 The Author(s). Published by S. Karger AG, Basel } \\
\text { www.karger.com/crg }\end{array}$ \\
\cline { 2 - 3 } & $\begin{array}{l}\text { Botey et al.: Long-Term Results of Serial Transverse Enteroplasty with Neovalve Creation } \\
\text { for Extreme Short Bowel Syndrome: Report of Two Cases }\end{array}$
\end{tabular}

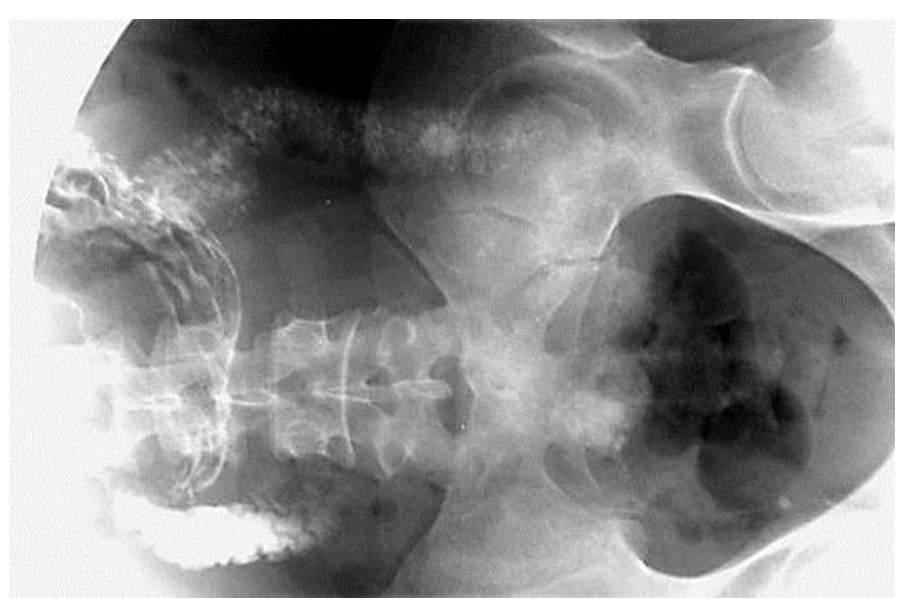

Fig. 1. Intestinal transit showed a residual bowel length of $34 \mathrm{~cm}$.

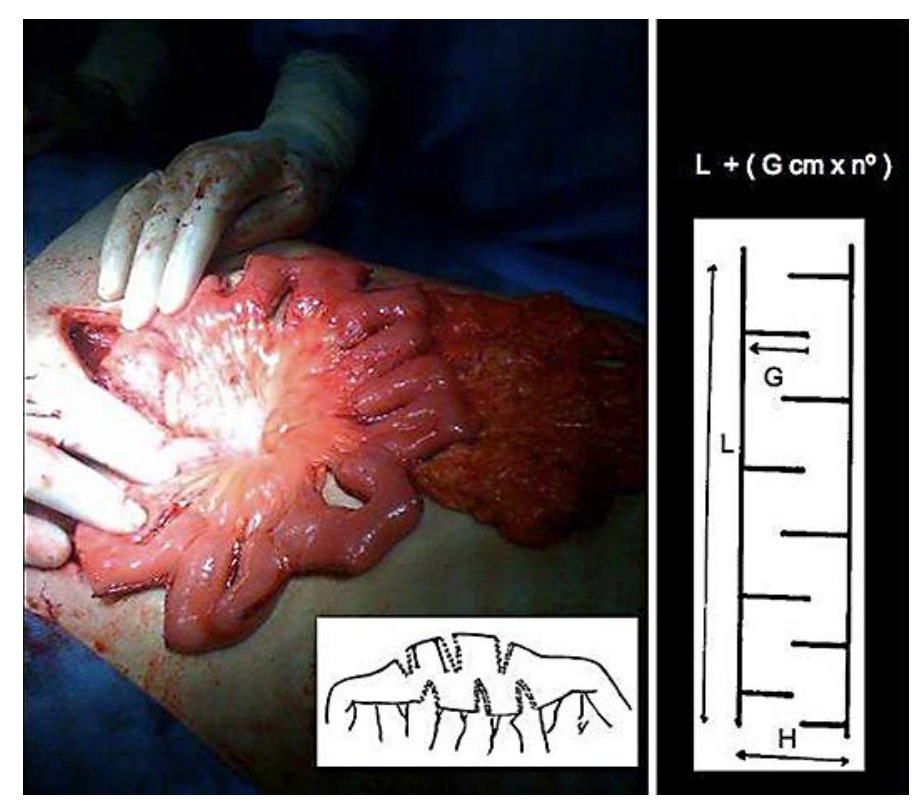

Fig. 2. Serial transverse enteroplasty technique. 


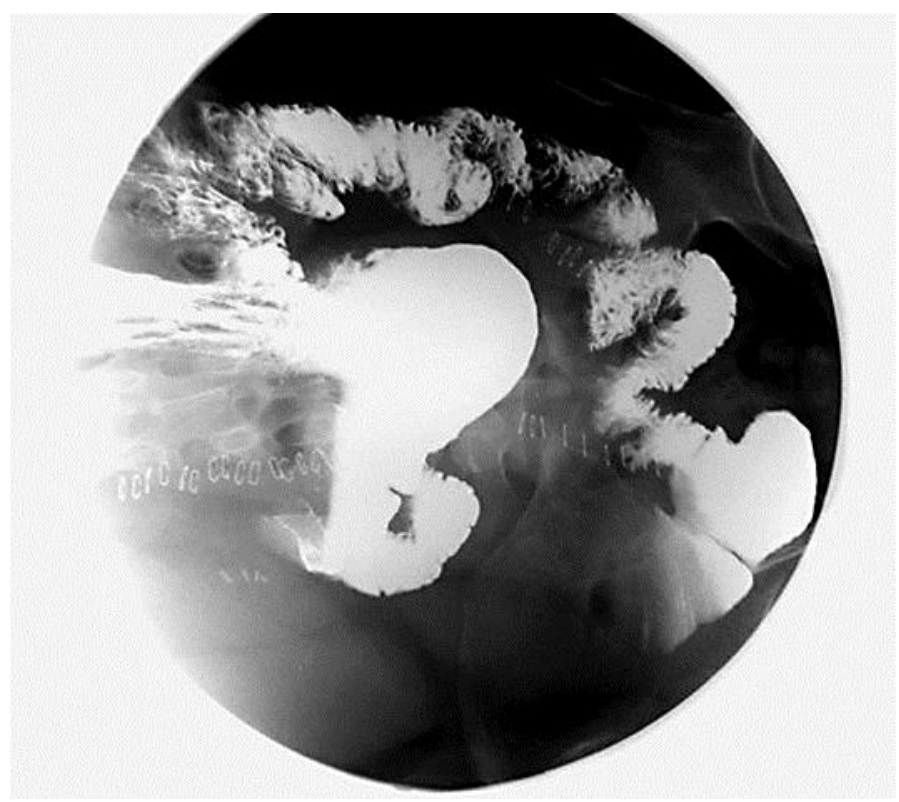

Fig. 3. Intestinal transit after serial transverse enteroplasty with $80 \mathrm{~cm}$ of bowel length.

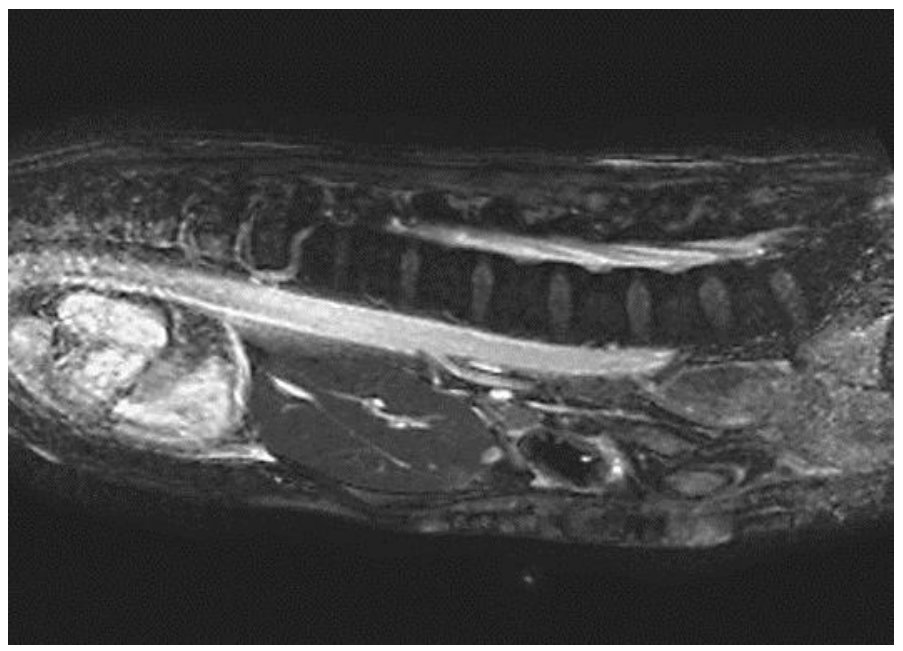

Fig. 4. Superior mesenteric artery syndrome also known as Wilkie syndrome. The aortomesenteric angle is $25^{\circ}\left(<30^{\circ}\right)$. 
Botey et al.: Long-Term Results of Serial Transverse Enteroplasty with Neovalve Creation for Extreme Short Bowel Syndrome: Report of Two Cases

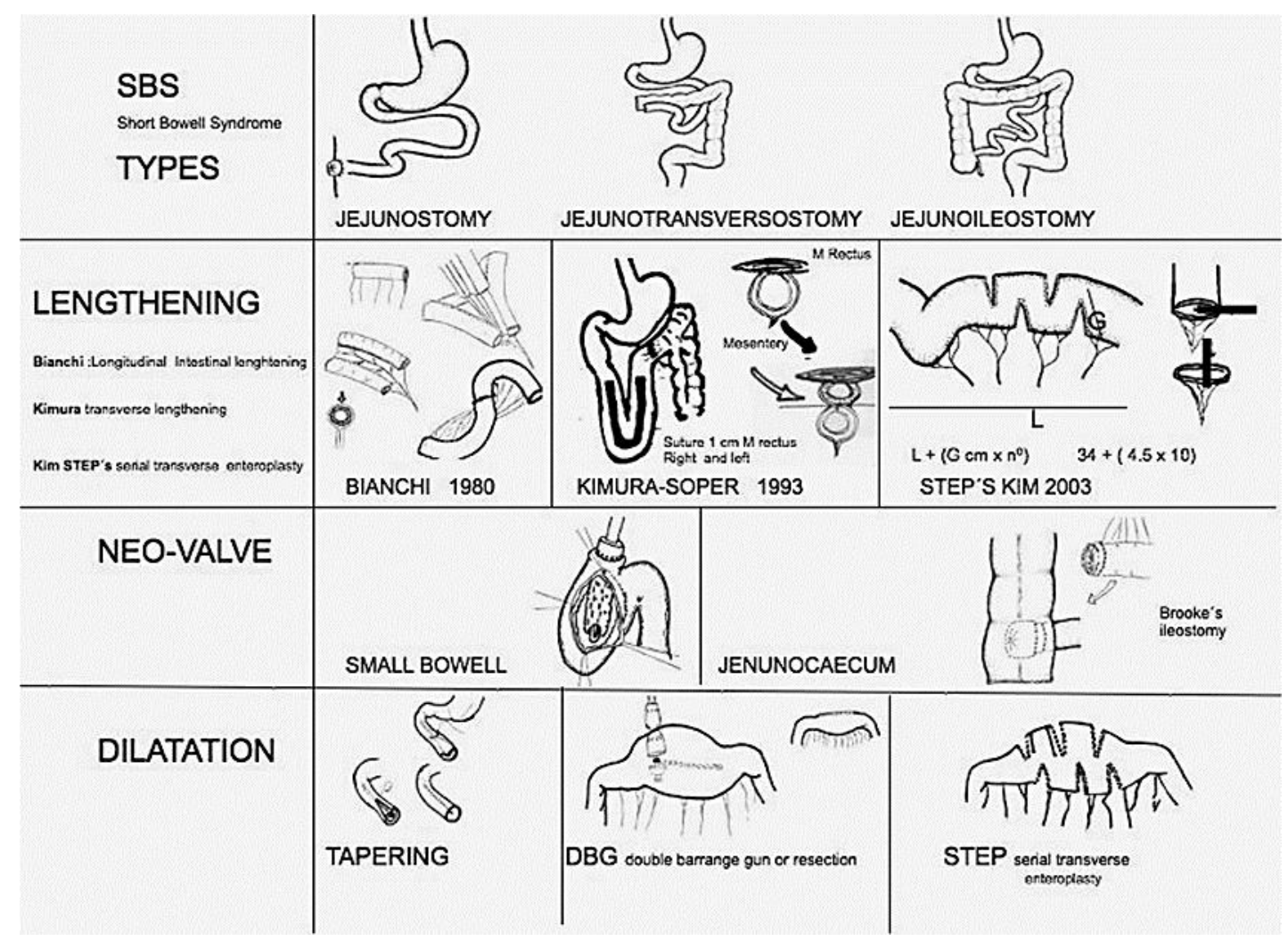

Fig. 5. Small bowel syndrome types, neovalve (Brooke Ileostomy), and techniques to solve bowel dilatations (tapering, double-barreled gun, and serial transverse enteroplasty). 
Botey et al.: Long-Term Results of Serial Transverse Enteroplasty with Neovalve Creation for Extreme Short Bowel Syndrome: Report of Two Cases

\section{ALGORITHM IN SMALL BOWELL SYNDROME : SURGICAL STRATEGIES}

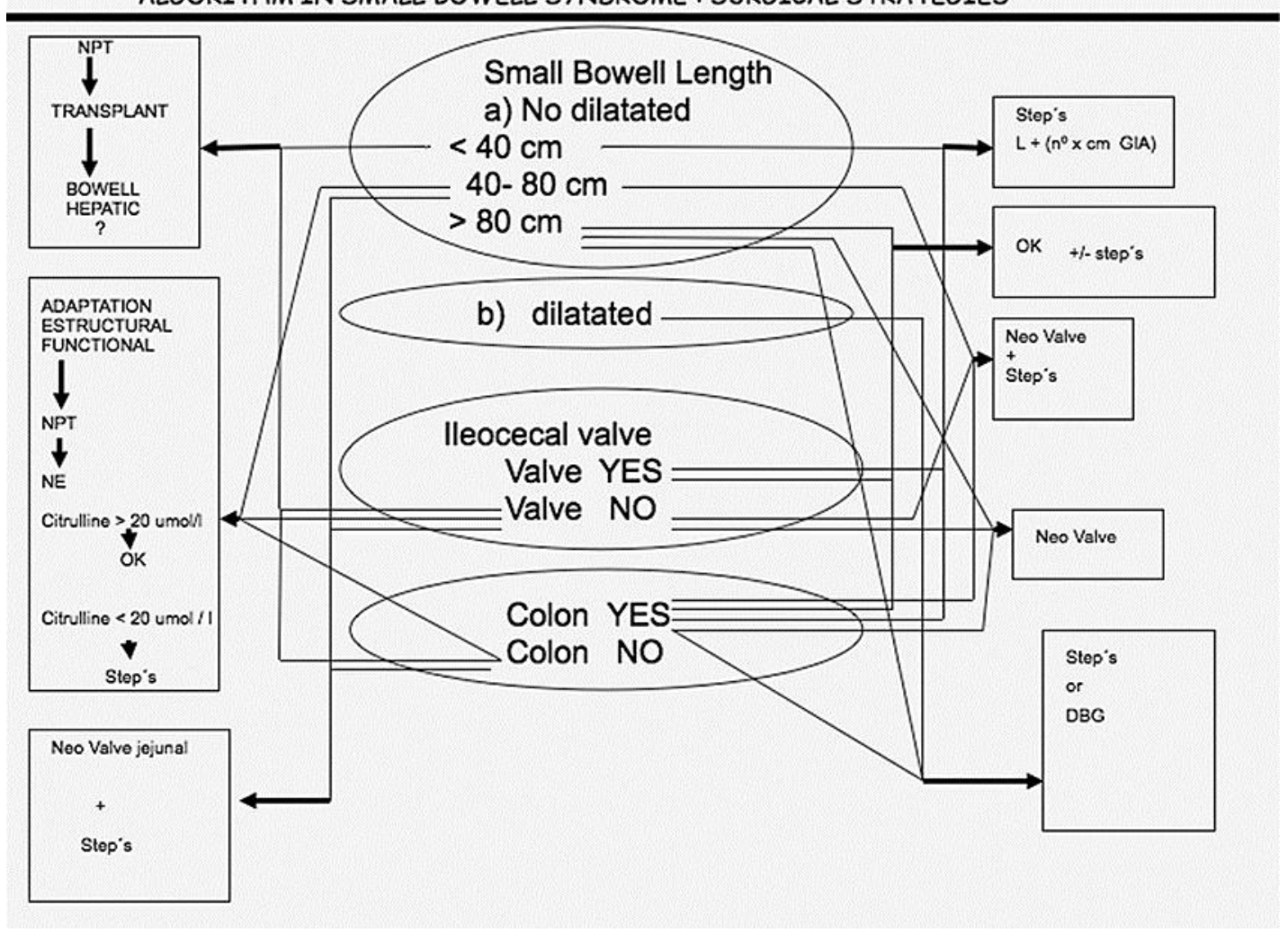

Fig. 6. Treatment algorithm for small bowel syndrome. Small bowel $<40 \mathrm{~cm}$ without ileocecal valve and colon: total parenteral nutrition (TPN), bowel and liver transplantation. Small bowel $<40 \mathrm{~cm}$ with ileocecal valve and colon: serial transverse enteroplasty (STEP). Small bowel $40-80 \mathrm{~cm}$ without ileocecal valve and colon: enteral nutrition and TPN, if citrulline <20: STEP. Small bowel 40-80 cm with ileocecal valve and colon: if citrulline $<20$ : STEP. Small bowel $>80 \mathrm{~cm}$ with ileocecal valve and colon: correct if citrulline $>20$. Small bowel $>80 \mathrm{~cm}$ without valve and colon: neovalve. Small bowel $>80 \mathrm{~cm}$ dilated with colon: STEP or double-barreled gun (DBG). 